\title{
ГЕНДЕРНІ ОСОБЛИВОСТІ ПОЄДНАННЯ СТАБІЛЬНОЇ ІШЕМІЧНОЇ ХВОРОБИ СЕРЦЯ ТА ХРОНІЧНОГО ОБСТРУКТИВНОГО ЗАХВОРЮВАННЯ ЛЕГЕНЬ
}

\begin{abstract}
Резюме. Дослідження демонструють динаміку гендерних особливостей ішемічної хвороби серця протягом останніх років. У випадку поєднання з хронічним обструктивним захворюванням легень клінічний перебіг патологій може змінюватись, що потребує оцінки залежно від статі пацієнтів.

Мета дослідження - визначити клініко-фрункціональні особливості перебігу стабільної ішемічної хвороби серця та хронічного обструктивного захворювання легень при їх поєднанні, залежно від статі пацієнтів.

Матеріали і методи. Обстежено 98 пацієнтів із поєднанням стабільної ішемічної хвороби серця та хронічного обструктивного захворювання легень, з них 78 чоловіків та 20 жінок. Проаналізовано дані загальноклінічного обстеження, тяжкість задишки за шкалою Medical Research Council (mMRC), тест з оцінки хронічного обструктивного захворювання легень (TOX), ЕКГ, показники спірограсрії, добового моніторування ЕКГ, ехокардіографії, параметри якості життя за анкетою MOS SF 36.

Результати досліджень та їх обговорення. Гендерних відмінностей за клінічними формами ішемічної хвороби серця, ступенем ураження коронарних артерій та групами хронічного обструктивного захворювання легень не встановлено. Показники функції зовнішнього дихання не відрізнялись у чоловіків та жінок, але для жінок характерна більш виражена задишка за даними анкетування $\mathrm{mMRC}(\mathrm{p}=0,007)$ та TOX $(p=0,009)$. Сумарний показник фізичного статусу якості життя у жінок нижче, ніж у

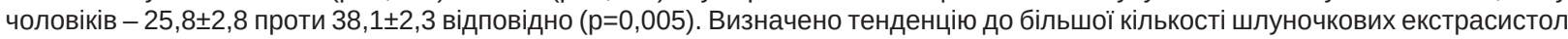
у чоловіків - $428(91 ; 1361)$ на добу, тоді як у жінок, - $247(7 ; 496)$ на добу. В усіх пацієнтів наявні ознаки ремоделювання лівих та правих камер серця, але достовірної гендерної відмінності не встановлено.

Висновки. У жінок із поєднанням стабільної ішемічної хвороби серця та хронічного обструктивного захворювання легень спостерігаються нижчі показники якості життя, більша потреба у медичній допомозі, порівняно з чоловіками, хоча достовірної відмінності між інструментальними показниками не виявлено.
\end{abstract}

Ключові слова: стабільна ішемічна хвороба серця; хронічне обструктивне захворювання легень; коморбідність; якість життя.

ВСТУП Ішемічна хвороба серця (IXC) та хронічне обструктивне захворювання легень (ХОЗЛ) - поширені хвороби внутрішніх органів, поєднання яких призводить до тяжчого перебігу патологій, зниження якості життя (ЯЖ) пацієнтів та зростання ризику ускладнень [1-4].

Відомо, що перебіг IXC має певні гендерні відмінності, зокрема результати когортних досліджень демонструють тяжче обструктивне ураження коронарних артерій в чоловіків, ніж у жінок, що підтверджено ангіоградрічно та, ймовірно, пов'язано із впливом тютюнокуріння та гіперхолестеринемії у чоловіків [5]. Разом з тим, ризик смерті та повторного інораркту міокарда (IM) після черезшкірних коронарних втручань (ЧКВ) у жінок вищий, ніж у чоловіків, що науковці пов'язують із старшим віком та більшою кількістю супутніх патологій у жінок [6].

Перебіг IXC має значний вплив на параметри ЯЖ та психологічний стан пацієнтів. Відомі результати досліджень вказують на нижчі показники Яж у жінок, котрим виконували ЧКВ, ніж у чоловіків, найбільший вплив на ЯЖ мали наявність цукрового діабету (ЦД), тривалість серцево-судинних захворювань та ступінь задишки [7]. Жінки з IXC, особливо молодших вікових груп, більш схильні до депресії, ніж чоловіки [8].

Протягом останніх років змінились погляди на перебіг ХОзЛ в осіб різної статі. Якщо раніше йшлося про вищу захворюваність та смертність від ХОЗЛ серед чоловіків, ніж серед жінок, то сучасні результати досліджень демонструють практично однакові показники [9]. Окрім того, у жінок, котрі курять, розвиваються тяжчкі обструктивні зміни порівняно з чоловіками [10].

За умови поєднання IXC та ХОЗЛ можливі зміни перебігу обох захворювань, що повинні бути оцінені у пацієнтів різної статі.

Метою дослідження було визначити клініко-фрункціональні особливості перебігу стабільної IXC та ХОЗЛ при їх поєднанні, залежно від статі пацієнтів.
МАТЕРІАЛИ І МЕТОДИ Обстежено 98 пацієнтів із поєднанням стабільної IXC та ХОЗЛ середнього віку $(65,8 \pm 0,83)$ року, 3 них чоловіків було 78 (79,6 \%), середній вік - $(60,5 \pm 0,86)$ року, жінок - 20 (20,4\%), середній вік $(70,1 \pm 2,9)$ року. Критерії включення в дослідження: вік понад 40 років, синусовий ритм, IXC підтверджено результатами коронаровентрикулографії (КВГ), реваскуляризації або даними анамнезу щодо перенесеного Q-інфраркту міокарда відповідно до наказу МО3 № 152 від 02.03.2016 р. [11], ХОЗЛ діагностовано відповідно до наказу МО3 № 555 від 27.06.2013 р. [12].

Усім пацієнтам проведено загальноклінічне обстеження, що включало збір скарг та анамнезу із вивченням попередньої медичної документації, об'єктивне дослідження, запис електрокардіограми (ЕКГ) (електрокардіограф "Юкард-200", "ЮАС"), спірометрію із використанням комп'ютерного спірограсра “MasterScopeCT", анкетування за тестом 3 оцінки ХОЗЛ (TOX) та визначення тяжкості задишки за модифрікованою шкалою медичної дослідницької ради (мМДР), добове моніторування ЕКГ на апараті DiaCard 03500 (Солвейг, АОЗТ м. Київ), ехокардіографрію (ЕхоКГ) в М- та В-режимах ("Logiq-500" фрірми GE, США), оцінку параметрів ЯЖ за українською версією анкети MOS SF 36. Статистичну обробку даних виконано з використанням пакета статистичних програм Statistica10.0 та MicrosoftExcel. Показники наведені як середнє значенняєстандартна похибка середньої величини $(\mathrm{M} \pm \mathrm{m})$, медіана та інтерквартильний інтервал між 25-м та 75-м персантилями. Достовірність різниці величин розраховано за критерієм $\chi^{2}$, U-тестом Манна-Уїтні, достовірними вважали результати порівнянь при значенні ймовірності похибки $р<0,05$.

РЕЗУЛЬТАТИ ДОСЛІДЖЕНЬ ТА ЇХ ОБГОВОРЕННЯ Встановлено, що за клінічними формами стабільної IXC чоловіки та жінки достовірно не відрізнялись: в обох групах переважали пацієнти з післяінфрарктним кардіо- 
склерозом (69,2 \% серед чоловіків та 75 \% серед жінок, $\mathrm{p}=0,61)$, близько $10 \%$ чоловіків та жінок мали повторний IM в анамнезі. За методами реваскуляризації різниці також не було, і серед чоловіків, і серед жінок було більше пацієнтів після стентування (28,2 та 20 \% відповідно, $\mathrm{p}=0,46)$, ніж після АКШ $(12,8$ та $15 \%, \mathrm{p}=0,81)$.

За клінічними групами ХОЗЛ достовірної відмінності між чоловіками та жінками не встановлено. У більшості обстежених діагностовано клінічну групу ХОЗЛ В, а саме, у 51,3 \% чоловіків та у $60 \%$ жінок (рис. 1).

Загалом, жінки мали багатосимптомний перебіг ХОЗЛ: серед жінок в групи В та D увійшло 19 осіб (95\%), серед чоловіків - 58 пацієнтів $(74,4 \%)(p=0,046)$.

При порівняльному аналізі показників дихальної системи визначений достовірно вищий бал задишки за шкалою мМДР та бал ТОХ у жінок ( $p=0,007$ та $p=0,009$ відповідно), ніж у чоловіків, хоча достовірної різниці за частотою дихання (ЧД) та показниками фрункції зовнішнього дихання (ФЗД) не виявлено (табл. 1).

При оцінці ехокардіограсрічних параметрів лівих відділів серця визначено тенденцію до зниження фрракції викиду лівого шлуночка (ФВ ЛШ) у чоловіків, порівняно із жінками, збільшення індексу маси міокарда лівого шлуночка (іММЛШ), кінцевого систолічного розміру ЛШ (КСР), кінцевого діастолічного розміру (КДР), кінцевого систолічного об'єму (КСО) та кінцевого діастолічного об'єму (КДО), але достовірної відмінності не виявлено (табл. 2).
Ремоделювання ЛШ різних типів було як серед чоловіків, так і серед жінок без достовірної відмінності.

Рівень середнього тиску в легеневій артерії (ЛА) не відрізнявся вірогідно в чоловіків та жінок, але серед жінок 95 \% склали пацієнтки із середнім рівнем тиску в ЛА (35-60 мм рт. ст.), тоді як серед чоловіків таких осіб було лише $71,9 \%$ ( $p=0,056)$. Серед чоловіків була значна частка пацієнтів (25,6 \%) із тиском в ЛА <35 мм рт. ст. (серед жінок $-5 \%, p=0,33$ ) та 2,5 \% чоловіків мали високий тиск в ЛА (понад 60 мм рт. ст.). Геометрія правого шлуночка (ПШ) була змінена у всіх обстежених пацієнтів: як серед чоловіків, так і серед жінок із поєднаною патологією частіше визначалось перевантаження ПШ тиском та об'ємом (у 83,3 та 65 \% осіб відповідно), але тенденція до більш частого перевантаження тиском та об'ємом простежувалась у чоловіків. Можливо, такі зміни можуть бути пов'язані зі збільшенням кількості осіб, що курили, серед чоловіків - 36 осіб (46,1 \%), тоді як серед жінок куріння не спостерігалось $(\mathrm{p}=0,002)$. Серед жінок частіше діагностували перевантаження ПШ тиском (35 \%), ніж серед чоловіків (14,1 $\%)(p=0,032)$. Перевантаження ПШ об'ємом діагностували у $2,6 \%$ чоловіків, тоді як серед жінок не виявлено.

Порівнюючи дані добового моніторування ЕКГ, достовірної різниці за кількістю порушень ритму встановлено не було (рис. 2).

Наявна тенденція до більшої кількості шлуночкових екстрасистол (ШЕ) у чоловіків - 428 (91; 1361) на добу,

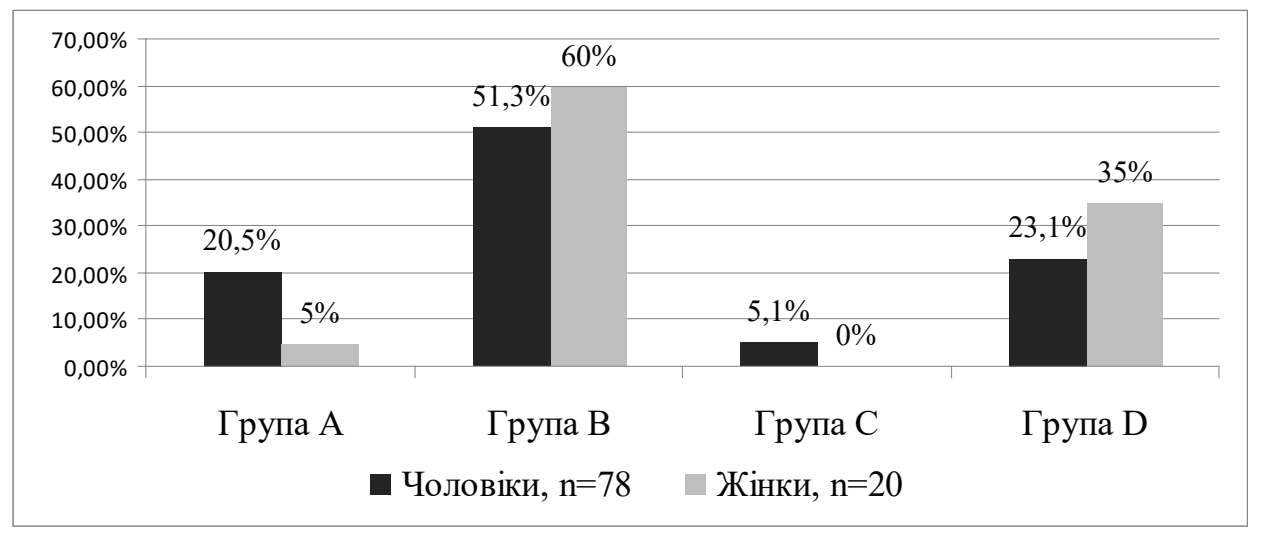

Рис. 1. Клінічні групи хронічного обструктивного захворювання легень у чоловіків та жінок із поєднаною патологією.

Таблиця 1. Клініко-функціональні параметри дихальної системи у чоловіків та жінок із поєднаною патологією

\begin{tabular}{|c|c|c|c|}
\hline Показник & Чоловіки (n=78) & Жінки $(\mathrm{n}=20)$ & $p$ \\
\hline ЧД на 1 хв & $\begin{array}{c}19,7 \pm 0,17 \\
19(17 ; 20) \\
\end{array}$ & $\begin{array}{c}20,2 \pm 0,3 \\
20(19 ; 21) \\
\end{array}$ & 0,11 \\
\hline TOX (бал) & $\begin{array}{c}17,1 \pm 1 \\
17(9 ; 24)\end{array}$ & $\begin{array}{c}22,9 \pm 1,6 \\
24(17 ; 27,5)\end{array}$ & 0,009 \\
\hline мМДР (бал) & $\begin{array}{c}2,1 \pm 0,11 \\
2(1 ; 3) \\
\end{array}$ & $\begin{array}{c}2,85 \pm 0,23 \\
3(2 ; 4)\end{array}$ & 0,007 \\
\hline $\mathrm{O} Ф \mathrm{~B}_{1}(\%)$ & $\begin{array}{c}62,2 \pm 1,85 \\
64(47 ; 75) \\
\end{array}$ & $\begin{array}{c}63,3 \pm 4,6 \\
56(49 ; 82,5) \\
\end{array}$ & 0,87 \\
\hline ФЖЄЛ (\%) & $\begin{array}{c}72,6 \pm 1,86 \\
75(62 ; 83)\end{array}$ & $\begin{array}{c}71,3 \pm 3,5 \\
(57 ; 81)\end{array}$ & 0,65 \\
\hline Індекс Тифно & $\begin{array}{c}64,3 \pm 0,9 \\
66(62 ; 67)\end{array}$ & $\begin{array}{c}62 \pm 1,9 \\
66(59 ; 67)\end{array}$ & 0,41 \\
\hline
\end{tabular}

Примітки: 1) дані кількісних показників представлені як $(\mathrm{M} \pm \mathrm{m})$ - середнє значення \pm математична похибка середнього і як Меd (реr25; per75) - медіана і міжквартильний розмах (25 і 75 персантиль):

2) порівняння медіан кількісних показників проводили за критерієм U Манна-Уїтні;

3) достовірною вважали різницю при $р<0,05$ між показниками чоловіків та жінок. 
Таблиця 2. Ехокардіографічні параметри пацієнтів різної статі з поєднаним перебігом ішемічної хвороби серця та хронічного обструктивного захворювання легень

\begin{tabular}{|c|c|c|c|}
\hline Показник & Чоловіки $(\mathrm{n}=78)$ & Жінки $(\mathrm{n}=20)$ & $p$ \\
\hline КДР (мм) & $\begin{array}{c}55 \pm 0,94 \\
55(50 ; 58) \\
\end{array}$ & $\begin{array}{c}51,7 \pm 2,2 \\
50(46 ; 55) \\
\end{array}$ & 0,10 \\
\hline KCP (MM) & $\begin{array}{c}39,2 \pm 0,89 \\
39(34 ; 44)\end{array}$ & $\begin{array}{c}36,7 \pm 2,4 \\
35,5(30 ; 41)\end{array}$ & 0,21 \\
\hline КСО (мл) & $\begin{array}{c}74,3 \pm 4,6 \\
68(47 ; 90) \\
\end{array}$ & $\begin{array}{c}63,9 \pm 9,8 \\
55(36 ; 88) \\
\end{array}$ & 0,25 \\
\hline КДО (мл) & $\begin{array}{c}143,6 \pm 5,3 \\
144(112 ; 164) \\
\end{array}$ & $\begin{array}{c}133,4 \pm 14,2 \\
121(95 ; 157) \\
\end{array}$ & 0,28 \\
\hline Ліве передсердя (мм) & $\begin{array}{c}40,4 \pm 1,36 \\
42(38 ; 45)\end{array}$ & $\begin{array}{c}41,2 \pm 1,7 \\
41,5(35,5 ; 46,5)\end{array}$ & 0,65 \\
\hline ФВ ЛШ (\%) & $\begin{array}{c}52,3 \pm 1,14 \\
51(46 ; 58)\end{array}$ & $\begin{array}{c}54,3 \pm 2,6 \\
56(46,5 ; 61) \\
\end{array}$ & 0,51 \\
\hline Товщина задньої стінки ЛШ (см) & $\begin{array}{c}1,23 \pm 0,03 \\
1,2(1,1 ; 1,3) \\
\end{array}$ & $\begin{array}{c}1,16 \pm 0,05 \\
1,17(1 ; 1,25) \\
\end{array}$ & 0,33 \\
\hline Товщина міжшлуночкової перетинки (см) & $\begin{array}{c}1,22 \pm 0,03 \\
1,2(1,1 ; 1,3) \\
\end{array}$ & $\begin{array}{c}1,15 \pm 0,04 \\
1,17(1 ; 1,25)\end{array}$ & 0,26 \\
\hline IMМЛШ (г/см²) & $\begin{array}{c}139,8 \pm 4,9 \\
140(111 ; 157)\end{array}$ & $\begin{array}{c}130 \pm 12,5 \\
126(106 ; 150)\end{array}$ & 0,42 \\
\hline Середній тиск у легеневій артерії (мм рт. ст.) & $\begin{array}{c}41,4 \pm 1,28 \\
41,5(34 ; 48)\end{array}$ & $\begin{array}{c}43,4 \pm 1,8 \\
41,5(41 ; 44,5)\end{array}$ & 0,58 \\
\hline Ознаки гіпо-, акінезу (абс., \%) & $59(75,6 \%)$ & $17(85 \%)$ & 0,55 \\
\hline Нормальна геометрія ЛШ (абс., \%) & $25(32 \%)$ & $5(25 \%)$ & 0,54 \\
\hline Концентричне ремоделювання ЛШ (абс., \%) & $19(24,4 \%)$ & $5(25 \%)$ & 0,95 \\
\hline Концентрична гіпертрофрія ЛШ (абс., \%) & $16(20,5 \%)$ & $5(25 \%)$ & 0,66 \\
\hline Ексцентрична гіпертрофрія ЛШ (абс., \%) & $18(23,1 \%)$ & $5(25 \%)$ & 0,85 \\
\hline
\end{tabular}

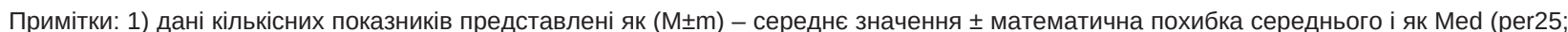
per75) - медіана і міжквартильний розмах (25 і 75 персантиль);

2) порівняння відсотків між групами проводили за критерієм $X^{2}$;

3) порівняння медіан кількісних показників проводили за критерієм U Манна-Уїтні;

4) достовірною вважали різницю при р<0,05 між показниками чоловіків та жінок.

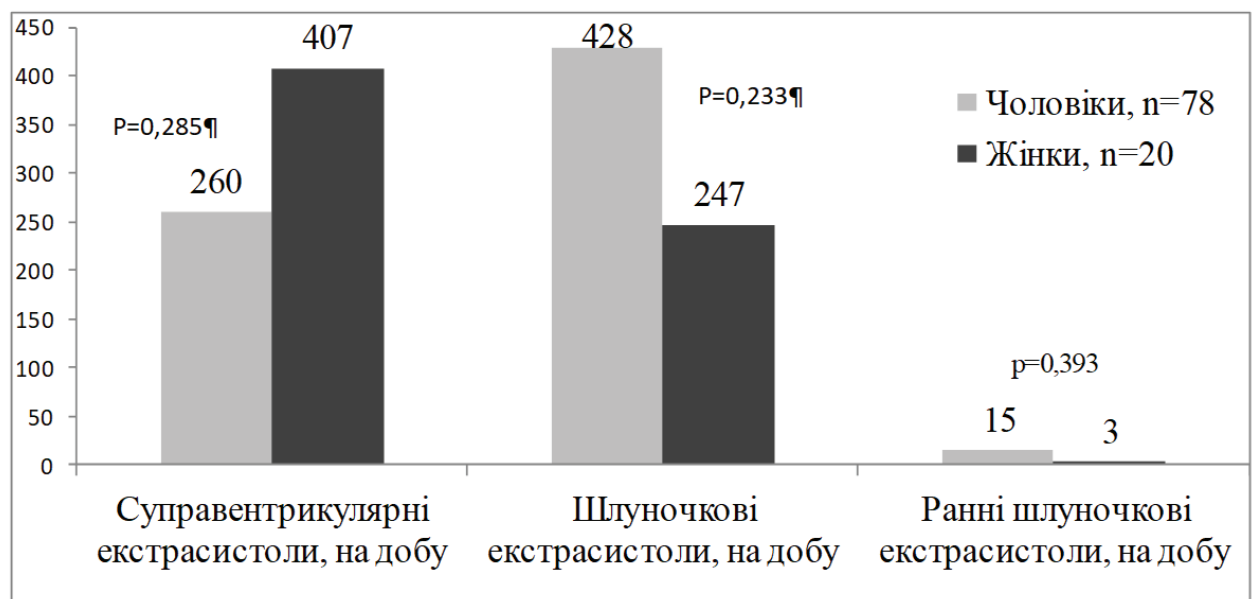

Рис. 2. Порушення ритму в чоловіків та жінок із поєднаною патологією за даними добового моніторування ЕКГ.

тоді як у жінок визначено 247 (7; 496) ШЕ на добу $(p=0,233)$. Пароксизмальні порушення ритму (фрібриляцію передсердь, пароксизми шлуночкової тахікардії) діагностували у $24(30,7 \%)$ чоловіків та у $3(15 \%)$ жінок (p=0,16).

Результати аналізу даних анкетування чоловіків та жінок щодо частоти звернень за медичною допомогою та параметрів ЯЖ виявили гендерні відмінності. Для жінок була характерною більша частота амбулаторних звернень до лікаря - 1 чи менше звернень серед жінок не було, тоді як серед чоловіків - 12,8 \% ( $p=0,093), 2$ рази на рік звертались $20 \%$ жінок та 19,2\% чоловіків ( $p=0,94)$, 3 рази на рік - $15 \%$ жінок та 26,9 \% чоловіків $(p=0,27), 4$ рази на рік - $25 \%$ жінок та $21,8 \%$ чоловіків $(p=0,76)$ та 5 разів на рік і більше зверталась найбільша кількість жінок - 40 \%, тоді як чоловіків лише 19,2 \% (

Частота госпіталізацій протягом 5 років була достовірно більшою серед жінок (у середньому $(6,5 \pm 0,7)$ раза $(4 ; 10))$, ніж чоловіків $(4,8 \pm 0,5)$ раза $(1 ; 8)(p=0,025)$, за 


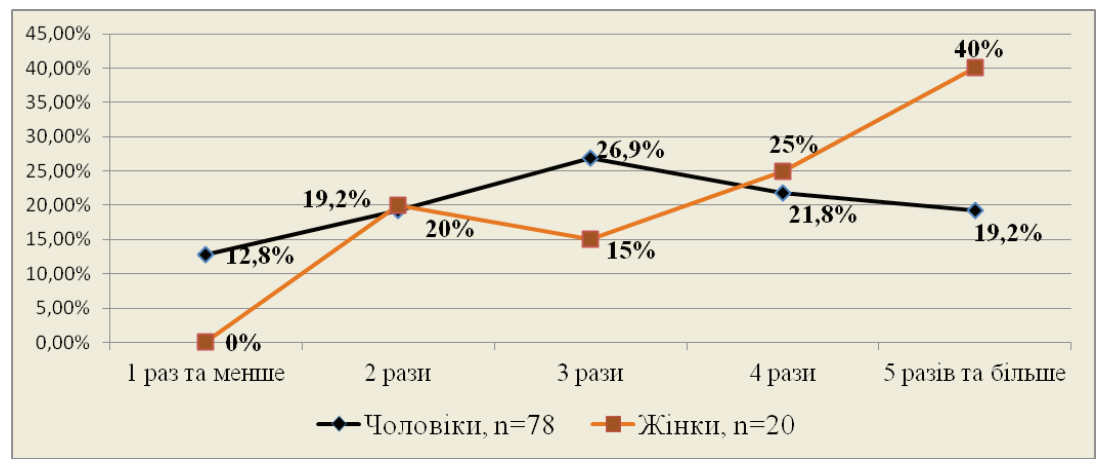

Рис. 3. Частота амбулаторних звернень за медичною допомогою серед чоловіків та жінок із поєднаною патологією.

екстреною допомогою жінки також звертались частіше, ніж чоловіки ( $p=0,026)$.

Порівняльна оцінка параметрів ЯЖ чоловіків та жінок із поєднанням стабільної IXC та ХОЗЛ демонструє тенденцію до нижчих показників у жінок, ніж у чоловіків, а саме: життєдіяльність більше обмежена через фрізичні та емоційні проблеми (РФ, РЕ), нижчий показник життєздатності (Ж3), загального сприйняття здоров'я (33) та загального розумового здоров'я (3Р3), а також більша частота та інтенсивність больового синдрому (Б).

Достовірна різниця спостерігається за показником фрізичної активності (ФА), тобто жінки відзначили більше обмеження побутової активності через неможливість виконання фрізичних навантажень, ніж чоловіки ( $<0,001)$ (табл. 3).

Сумарні шкали визначили тенденцію до зниження психічного та загального статусу (ПС, ЗС) жінок та досто- вірне зниження срізичного статусу (ФС), порівняно із пацієнтами чоловічої статі, що мають поєднання IXC та ХОЗЛ.

ВИСНОВКИ 1. Клінічні фрорми IXC, тяжкість ураження коронарних артерій та потреба в реваскуляризаційних втручаннях суттєво не відрізнялась у чоловіків та жінок.

2. За перебігом ХОЗЛ для жінок характерна більш виражена клінічна симптоматика, зокрема тяжкість задишки за мМДР та ТОХ, ніж у чоловіків, за відсутності достовірних відмінностей показників ФЗД.

3. Жінки із поєднанням стабільної IXC та ХОЗЛ частіше звертаються за медичною допомогою, ніж чоловіки, та відмічають погіршення параметрів ЯЖ більше від чоловіків, достовірно відрізняються показники ФС ЯЖ.

4. Спостерігається тенденція до зниження ФВ ЛШ та дилатації порожнини лівих відділів серця у чоловіків порівняно із жінками.

Таблиця 3. Показники якості життя чоловіків та жінок із поєднанням стабільної ішемічної хвороби серця та хронічного обструктивного захворювання легень

\begin{tabular}{|c|c|c|c|}
\hline Показник & Чоловіки $(\mathrm{n}=78)$ & Жінки $(n=20)$ & $p$ \\
\hline Фізична активність (бал) & $\begin{array}{c}48,9 \pm 2,8 \\
50(33 ; 66)\end{array}$ & $\begin{array}{c}27,5 \pm 4,6 \\
22,2(11 ; 44)\end{array}$ & 0,00064 \\
\hline $\begin{array}{l}\text { Роль фізичних проблем в обмеженні життєдіяль- } \\
\text { ності (бал) }\end{array}$ & $\begin{array}{c}12,7 \pm 3,8 \\
0(0)\end{array}$ & $\begin{array}{c}1,3 \pm 1,3 \\
0(0)\end{array}$ & 0,091 \\
\hline Біль (бал) & $\begin{array}{c}53,1 \pm 2,6 \\
55(45 ; 67,5) \\
\end{array}$ & $\begin{array}{c}48,5 \pm 4,4 \\
45(45 ; 57,5)\end{array}$ & 0,424 \\
\hline Соціальна активність (бал) & $\begin{array}{c}64,9 \pm 3,1 \\
62,5(50 ; 87,5) \\
\end{array}$ & $\begin{array}{c}57,9 \pm 3,8 \\
50(50 ; 75) \\
\end{array}$ & 0,192 \\
\hline Загальне розумове здоров'я (бал) & $\begin{array}{c}52,8 \pm 2,6 \\
52(36 ; 72) \\
\end{array}$ & $\begin{array}{c}49,1 \pm 4,6 \\
48(32 ; 60)\end{array}$ & 0,521 \\
\hline $\begin{array}{l}\text { Роль емоційних проблем в обмеженні життєді- } \\
\text { яльності (бал) }\end{array}$ & $\begin{array}{c}53,3 \pm 5,8 \\
66,6(0 ; 100)\end{array}$ & $\begin{array}{c}52,6 \pm 10,3 \\
33,3(0 ; 100)\end{array}$ & 0,985 \\
\hline Життєздатність (енергія, втома) (бал) & $\begin{array}{c}31,9 \pm 2,3 \\
30(20 ; 40)\end{array}$ & $\begin{array}{c}24,7 \pm 3,4 \\
20(10 ; 35)\end{array}$ & 0,114 \\
\hline Загальне сприйняття здоров'я (бал) & $\begin{array}{c}31,7 \pm 2,1 \\
30(20 ; 45)\end{array}$ & $\begin{array}{c}28,4 \pm 3,5 \\
25(15 ; 40)\end{array}$ & 0,461 \\
\hline Здоров'я порівняно з минулим роком (бал) & $\begin{array}{l}25,8 \pm 2,6 \\
25(0 ; 50)\end{array}$ & $\begin{array}{c}29,7 \pm 4,2 \\
25(25 ; 50)\end{array}$ & 0,445 \\
\hline Фізичний статус (бал) & $\begin{array}{c}38,1 \pm 2,3 \\
35,5(26 ; 43)\end{array}$ & $\begin{array}{c}25,8 \pm 2,8 \\
22,9(18 ; 34) \\
\end{array}$ & 0,005 \\
\hline Психічний статус (бал) & $\begin{array}{c}31,7 \pm 1,9 \\
30(20 ; 40)\end{array}$ & $\begin{array}{c}26,6 \pm 2,9 \\
25(15 ; 37,5)\end{array}$ & 0,21 \\
\hline Загальний статус (бал) & $\begin{array}{c}57,4 \pm 3,2 \\
55(32,9 ; 80,9)\end{array}$ & $\begin{array}{c}53 \pm 5,2 \\
42,6(37 ; 75,3)\end{array}$ & 0,488 \\
\hline
\end{tabular}

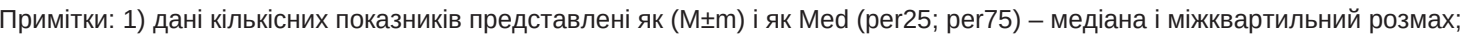

2) порівняння проводили за критерієм U Манна-Уїтні;

3) достовірною вважали різницю при р<0,05 між показниками чоловіків та жінок. 
Перспективи подальших досліджень полягають в індивідуалізації підходу в курації пацієнтів із по- єднаною патологією, враховуючи гендерні особливості.

\section{СПИСОК ЛІТЕРАТУРИ}

1. Impact of chronic obstructive pulmonary disease on long-term outcome in patients with coronary artery disease undergoing percutaneous coronary intervention / M. Zhang, Y. J. Cheng, W. P. Zheng [et al.] // Biomed. Res. Int. - 2016. - doi: 10.1155 / 2016/8212459.

2. Risk of myocardial infarction (MI) and death following $\mathrm{MI}$ in people with chronic obstructive pulmonary disease (COPD): a systematic review and meta-analysis / K. J. Rothnie, R. Yan, L. Smeeth, J. K. Quint // BMJ Open. - 2015. - Vol. 5 (9). - P. 134-139.

3. Underdiagnosis and prognosis of chronic obstructive pulmonary disease after percutaneous coronary intervention a prospective study $/$ P. Almargo, A. Lapuente, J. Pareja [et al.] // International Journal of COPD. - 2015. - Vol. 10. - P. 1353-1361.

4. Kulik A. Quality of life after coronary artery bypass graft surgery versus percutaneous coronary intervention: what do the trials tell us I A. Kulik // Curr. Opin. Cardiol. - 2017. - Vol. 32 (6). - P. 707-714.

5. Sex differences in independent factors associated with coronary artery disease / A. Suessenbacher, M. Wanitschek, J. Dörler [et al.] // Wien Klin. Wochenschr. - 2014. - Vol. 126 (21-22). - P. 718-726. doi: 10.1007/s00508-014-0602-9.

6 . Sex differences in the outcome after percutaneous coronary intervention - A propensity matching analysis. / G. Ndrepepa, S. Kufner, K. Mayer [et al.] // Cardiovasc. Revasc. Med. - 2018. doi: 10.1016/j.carrev.2018.05.010.

7. Gender differences in health-related quality of life in patients undergoing coronary angiography / C. M. Gijsberts, P. Agostoni,
I. E. Hoefer [et al.] // Open Heart. - 2015. - Vol. 27; 2 (1): e000231. doi: 10.1136/openhrt-2014-000231.

8. Sex and age differences in the association of depression with obstructive coronary artery disease and adverse cardiovascular events / A. J. Shah, N. Ghasemzadeh, E. Zaragoza-Macias [et al.] // J. Am. Heart Assoc. - 2014. - Vol. 18; 3 (3): e000741. doi: 10.1161/ JAHA.113.000741

9. Global Initiative for Chronic Obstructive Lung Disease (Updated 2018) // [Electronic Resourses]: www.goldcopd.com

10. Sex-related differences in bronchial parameters and pulmonary function test results in patients with chronic obstructive pulmonary disease based on three-dimensional quantitative computed tomography / Y. Li, Y. L. Dai, N. Yu, Y. M. Guo // J. Int. Med. Res. -2018. - Vol. 46 (1). -P. 135-142. doi: 10.1177 / 0300060517721309.

11. Про затвердження та впровадження медико-технологічних документів зі стандартизації медичної допомоги при стабільній ішемічній хворобі серця. Унісрікований клінічний протокол первинної, вторинної (спеціалізованої) та третинної (високоспеціалізованої) медичної допомоги “Стабільна ішемічна хвороба серця": наказ МО3 України № 152 від 02.03.2016 [Електронний ресурс] / Режим доступу : http://moz.gov.ua/ua/portal/dn_20160302_0152.html.

12. Про затвердження та впровадження медико-технологічних документів зі стандартизації медичної допомоги при хронічному обструктивному захворюванні легень : наказ МОЗ України № 555 від 27.06.2013 [Електронний ресурс] / Режим доступу : http:// moz.gov.ua/ua/portal/dn_20130627_0555.html

Отримано 06.08.18

Електронна адреса для листування: larchyk@gmail.com

\section{GENDER FEATURES OF THE COMBINATION OF STABLE ISCHEMIC HEART DISEASE AND CHRONIC OBSTRUCTIVE PULMONARY DISEASE}

Summary. Studies show the dynamics of gender characteristics of ischemic heart disease in recent years. In the case of combination with chronic obstructive pulmonary disease, the clinical course of the pathologies may vary, which needs to be evaluated depending on the gender of the patients.

The aim of the study - to determine the clinical and functional characteristics of the course of combination of stable ischemic heart disease and chronic obstructive pulmonary disease according to the gender of patients.

Materials and Methods. 98 patients with a combination of stable ischemic heart disease and chronic obstructive pulmonary disease, including 78 men and 20 women, were examined. The data of general clinical examination, severity of shortness of breath for modified Medical Research Council (mMRC) and COPD assesstment test (CAT), ECG, spirography, daily ECG monitoring, echocardiography, quality of life parameters according to the MOS SF 36 questionnaire were evaluated.

Results and Discussion. Differences in the clinical forms of ischemic heart disease, the degree of damage of coronary arteries and the groups of chronic obstructive pulmonary disease have not been established. Indicators of the function of external respiration did not differ between men and women, but women were characterized by more severe dyspnea according to the questionnaire of mMRC $(p=0.007)$ and CAT $(p=0.009)$.

The overall indicator of the physical status of quality of life in women is lower than in men $-(25.8 \pm 2.8)$ against $(38.1 \pm 2.3)$, respectively $(p=0.005)$. The tendency to a greater number of ventricular extrasystoles in men is determined - $428(91 ; 1361)$ per day, whereas in women $247(7 ; 496)$ are determined per day. All patients have signs of remodeling of the left and right chambers of the heart, but no gender difference is established.

Conclusions. Women with a combination of stable ischemic heart disease and chronic obstructive pulmonary disease have lower quality of life indicators, a greater need for medical care than men, although there is no significant difference in instrumental indicators.

Key words: stable ischemic heart disease; chronic obstructive pulmonary disease; comorbidity; quality of life. 
Сю. М. Мостовой, Л. В. Распутина, Д. В. Диденко Винницкий национальный медицинский университет имени Н. И. Пирогова

\section{ГЕНДЕРНЫЕ ОСОБЕННОСТИ СОЧЕТАНИЯ СТАБИЛЬНОЙ ИШЕМИЧЕСКОЙ БОЛЕЗНИ СЕРДЦА И ХРОНИЧЕСКОЙ ОБСТРУКТИВНОЙ БОЛЕЗНИ ЛЕГКИХ}

Резюме. Исследования демонстрируют динамику гендерных особенностей ишемической болезни сердца на протяжении последних лет. В случае сочетания с хроническим обструктивным заболеванием легких клиническое течение патологий может быть изменено, что требует оценки в зависимости от пола пациентов.

Цель исследования - определить клинико-функциональные особенности течения стабильной ишемической болезни сердца и хронической обструктивной болезни легких при их сочетании в зависимости от пола пациентов.

Материалы и методы. Обследовано 98 пациентов с сочетанием стабильной ишемической болезни сердца и хронического обструктивного заболевания легких, из них 78 мужчин и 20 женщин. Проанализированы данные общеклинического обследования, тяжесть одышки по модифицированной шкале Medical Research Council (mMRC), тест оценки хронической обструктивной болезни легких (ТОX), ЭКГ, показатели спирографии, суточного мониторирования ЭКГ, эхокардиографии, параметры качества жизни по анкете MOS SF 36.

Результаты исследований и их обсуждение. Гендерных различий по клиническим фрормам ишемической болезни сердца, степени поражения коронарных артерий и группах хронического обструктивного заболевания легких не установлено. Показатели функции внешнего дыхания не отличались у мужчин и женщин, но для женщин характерна более выраженная одышка по данным анкетирования $\mathrm{MMRC}(\mathrm{p}=0,007)$ и TOX ( $=0,009)$. Суммарный показатель фризического статуса качества жизни у

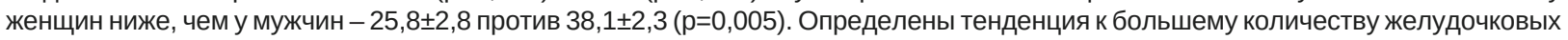
экстрасистол у мужчин - $428(91 ; 1361)$ в сутки, тогда как у женщин - $247(7 ; 496)$ в сутки. У всех пациентов имеются признаки ремоделирования левых и правых камер сердца, но достоверного гендерного различия не установлено.

Выводы. У женщин с сочетанием стабильной ишемической болезни сердца и хронического обструктивного заболевания легких наблюдаются низкие показатели качества жизни, большая потребность в медицинской помощи, по сравнению с мужчинами, хотя достоверного различия между инструментальными показателями не выявлено.

Ключевые слова: стабильная ишемическая болезнь сердца; хронические обструктивные заболевания легких; коморбидность; качество жизни. 